\title{
ARE THERE ANY ADVANTAGES OF GENETICALLY DIVERSE MATERIAL IN CEREAL BREEDING PROGRAMMES FOR ORGANIC FARMING?
}

\author{
Vija Strazdiṇa*, Indra Beinaroviča**, Linda Legzdina ${ }^{* *}$, and Arta Kronberga** \\ * State Stende Cereal Breeding Institute, Dižstende, „Dižzemes”, Lïbagu pag., Talsu nov., LV-3258, LATVIA; \\ vijastrazdina@inbox.Iv \\ ** State Priekuḷi Plant Breeding Institute, Zinātnes iela 2, Priekuḷi, Priekuḷu pag., Priekuḷu nov., LV-4126, LATVIA
}

Communicated by Isaak Rashal

\begin{abstract}
Employing cereal genetic variation in breeding programmes for organic farming is one of the ways to create varieties with higher stability and adaptability. The aim of the study was to compare and evaluate grain yield, quality and other traits of barley pure lines, hybrid populations, variety mixtures, as well as winter wheat hybrid populations and parental varieties, in organic and conventional farming systems. Significant evidence for advantages of using barley mixtures and populations under organic and conventional management systems was not observed. More advantages with respect to yield, adaptability to unfavourable environments and TGW were observed for breeding lines selected for suitability to organic conditions. Combination of distinctive genotypes may result in a fairly stable mixture with average yield above the components. The study confirmed that resistance of winter wheat genotypes to abiotic stress is one of the significant traits that is closely connected with limitation of the wheat productivity in both growing conditions. Yield and grain quality value of winter wheat genotypes was lower under organic conditions compared to a conventional growing system. Advantages of populations were not observed under organic conditions, but significantly higher yield, in comparison to parental varieties, was obtained for two populations in conventional conditions. In general, the yield of populations was intermediate to that of the parents.
\end{abstract}

Key words: spring barley, winter wheat, pure lines, mixtures, populations, organic and conventional farming system.

\section{INTRODUCTION}

The model of self-pollinating cereal crop breeding for a conventional system is to develop genetically uniform varieties - pure lines that are highly productive under optimal agronomic conditions with high inputs of fertilisers and crop protection chemicals (Lammerts et al., 2007). Breeding for sustainability is a process of applying varieties to an environment instead of changing circumstances. In organic and low input agriculture systems the genetically uniform lines can have limited ability to adapt to environmental changes (Murphy et al., 2007). The grain yield and quality of cereals in organic farming is much more influenced by the interaction of the genotype and environment than in the conventional system (Konvalina and Moudrý, 2007).

Agrobiodiversity is now viewed as a key component of sustainable farming systems. The presence of genetic diversity within a field stabilises production and provides much more than do monocultures (Chaitel et al., 2010). Employing genetic variation in breeding programmes for organic farming can allow to develop varieties with higher stability and adaptability. There are several methods of using genetic heterogeneity to increase grain yield level and quality, and resistance to diseases, which included growing of variety mixtures and hybrid populations (Lammerts et al., 2007). Variety mixtures have been shown to have stability of yield, which may result from more effective restriction of both biotic and abiotic stresses Thus, while a mixture may not out-yield the best individual variety at any given site, ranking orders within mixtures are subject to much less variation between environments than are the ranking orders of single varieties (Finckh et al., 2000; Wolfe, 2000; Swanston et al., 2005).

Alternative approaches to pure line breeding have been developed, including population breeding. Populations have much greater variation, as typically every plant represents a distinct genotype. This genetic variation in the field has the potential to adapt through natural selection to different and changing environmental conditions and to provide more stable yield in variable environments (Murphy, et al., 2005; Finckh et al., 2010). 
Winter hardiness is a very important trait for wheat in all environments in Latvian agroclimatical conditions. Results of studies have confirmed that resistance of populations to abiotic stresses is closely connected with parent traits. Parents with better values used in a cross result in the best population, unless negative genetic correlation proves otherwise (Murphy et al., 2007). In winter wheat breeding programmes for organic and low input conditions, it is necessary to involve genotypes with better nutrient-efficiency to contribute to crop robustness (Lammerts, 2010). The aim of this study was to compare and evaluate grain yield, quality and other traits of barley pure lines, hybrid populations, genotype mixtures, as well as winter wheat hybrid populations and parental varieties in organic and conventional farming systems.

\section{MATERIALS AND METHODS}

Spring barley field trials were carried out in 2010 and 2011 in Priekuli in four locations with distinct crop rotations: $\mathrm{C} 1$ - conventional breeding field, $\mathrm{C} 2$ - conventional seed production field, $\mathrm{O} 1$ - organic trial and seed production field, and $\mathrm{O} 2$ - organic farm. Four distinct varieties along with breeding lines, populations and mixtures developed from them (Table 1) were sown in four replications of 12.3 $\mathrm{m}^{2}$ plots in a randomised complete block design with seed rate 400 untreated seeds able to germinate per $\mathrm{m}^{2}$. Breeding lines with traits suitable for organic farming were selected during $\mathrm{F}_{3}-\mathrm{F}_{6}$ generations. The seed for populations was multiplied in the respective location starting from the $F_{4}$ generation. The seed for other genotypes was obtained from the location $\mathrm{O} 1$; seed mixtures were prepared every year by mixing the components $1: 1$ according to germination ability. Trials were carried out on sod-podzolic loamy sand (except loam in C2 in 2011); soil properties are summarised in Table 2. In $\mathrm{C} 1$ and $\mathrm{C} 2$ the pre-crop was potato; mineral fertiliser with $\mathrm{N} 80-83 \mathrm{~kg} \mathrm{ha}^{-1}, \mathrm{P} 45-48 \mathrm{~kg} \mathrm{ha}^{-1}$ and $\mathrm{K} 75-84$ $\mathrm{kg} \mathrm{ha}^{-1}$ as well as herbicide was applied.

Winter wheat. The trials were conducted in two growing seasons 2009-2011 in Stende and in Priekuli in three sites. In 2009/2010, ten hybrid populations (F4 to F7) were selected under the conventional breeding programme and evaluated in Stende and Priekuli under organic conditions and 23 parental varieties assessed in Stende under organic and conventional conditions. Two populations and seven parental varieties were excluded from further investigations, as all plants died during winter in both sites.

Plot size was $5 \mathrm{~m}^{2}$, in four replications; seed rate - treated 500 seeds able to germinate per $\mathrm{m}^{2}$ used for $\mathrm{C}$ and 550 untreated seeds used for $\mathrm{O}$ field.

In the conventional field the pre-crop was white mustard; mineral fertiliser before sowing was applied as $\mathrm{N} 15 \mathrm{~kg}$ $\mathrm{ha}^{-1}, \mathrm{P} 45 \mathrm{~kg} \mathrm{ha}^{-1}$ and $\mathrm{K} 90 \mathrm{~kg} \mathrm{ha}^{-1}$, and after plant regeneration, surface fertilisation of NP $364 \mathrm{~kg} \mathrm{ha}^{-}{ }^{1}$ and N 135 $\mathrm{kg} \mathrm{ha}^{-1}$ was used as well as herbicide application. Organic fields were managed according to organic standards, and the winter wheat pre-crop in this case was pea. Trials were arranged on sod-podzolic loamy sand. Soil properties are summarised in Table 3.

The traits winter hardiness, grain yield, and quality (content of crude protein, content of gluten, Sedimentation Value and thousand grain weight (TGW) were evaluated.

Winter wheat infection level with snow mould Fusarium nivale Ces. was scored using the scale 1 to 9 (1 - variety resistant to snow mould; $9-100 \%$ infected) and winter hardiness scored as 1-9 (9 - high winter hardiness).

For both barley and wheat, grain yield was assessed by the direct method and was recalculated to $14 \%$ moisture content, thousand grain weight (TGW) by standard method (LV ST ZM 43-95), volume weight, content of crude protein and starch in dry matter by using a Near Infrared Transmittance grain analyser Infratec 1241.

Two-factor ANOVA was used for statistical analysis (except single-factor ANOVA for barley lodging data). To

Table 1

BARLEY GENOTYPES INCLUDED IN THE TRIAL

\begin{tabular}{|c|c|c|}
\hline & $\begin{array}{l}\text { ents of mixture } \\
\text { components }\end{array}$ & Denomination \\
\hline \multirow[t]{2}{*}{ pure lines } & q 'Primus', ठ’ 'Idumeja' & line 1, line 2 \\
\hline & 申 ‘Anni', ठૈ‘Dziugiai’ & line 3, line 4, line 5 \\
\hline \multirow[t]{2}{*}{ populations } & 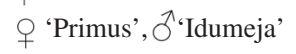 & population 1 (F7-F8) \\
\hline & @ ‘Anni', O’‘Dziugiai’ & population $2(\mathrm{~F} 7-\mathrm{F} 8)$ \\
\hline \multirow[t]{4}{*}{ mixtures } & line $3+$ line 4 & mixture 1 \\
\hline & line $2+$ line 5 & mixture 2 \\
\hline & 'Primus' + 'Idumeja' & mixture 3 \\
\hline & 'Anni’ + 'Dziugiai' & mixture 4 \\
\hline
\end{tabular}

Table 2

SOIL AGROCHEMICAL PROPERTIES IN BARLEY TESTING LOCATIONS

\begin{tabular}{l|l|l|l|l|l|l|l|l}
\hline \multirow{2}{*}{$\begin{array}{c}\text { Soil } \\
\text { characteristics }\end{array}$} & \multicolumn{4}{|c|}{2010} & \multicolumn{4}{c}{2011} \\
\cline { 2 - 10 } & $\mathrm{O} 1$ & $\mathrm{O} 2$ & $\mathrm{C} 1$ & $\mathrm{C} 2$ & $\mathrm{O} 1$ & $\mathrm{O} 2$ & $\mathrm{C} 1$ & $\mathrm{C} 2$ \\
\hline Soil pH KCL & 5.7 & 6.5 & 5.5 & 5.6 & 5.4 & 6.6 & 5.4 & 4.5 \\
Humus content, \% & 2.8 & 3.5 & 2.6 & 2.8 & 2.1 & 3.0 & 3.0 & 2.3 \\
$\mathrm{~K}_{2} \mathrm{O}, \mathrm{mg} \mathrm{kg}^{-1}$ & 144 & 173 & 132 & 159 & 98 & 167 & 165 & 155
\end{tabular}

Table 3

SOIL AGROCHEMICAL PROPERTIES IN WHEAT TESTING LOCATIONS

\begin{tabular}{l|ccc|c|c|c}
\hline \multirow{2}{*}{ Soil characteristics } & \multicolumn{2}{|c|}{2010} & \multicolumn{3}{c}{2011} \\
\cline { 2 - 6 } & O (Stende) & C ( Stende) & O (Stende) & O (Priekuli) & C \\
\hline Soil pH KCL & 6.89 & $5.9-6.1$ & 6.75 & 4.98 & 6.75 \\
Humus content, \% & 2.9 & $2.2-2.6$ & 3.0 & 2.5 & 2.6 \\
$\mathrm{~K}_{2} \mathrm{O}, \mathrm{mg} \mathrm{kg}^{-1}$ & 114 & $102-129$ & 119 & 74.4 & 105 \\
$\mathrm{P}_{2} \mathrm{O}_{5}, \mathrm{mg} \mathrm{kg}^{-1}$ & 167 & $162-237$ & 156 & 67.8 & 189
\end{tabular}


evaluate spring barley and wheat yield stability and adaptability, regression of yield on environmental indexes was done. For barley, pairs composed of parents and material derived from them were processed in separate groups ('Primus'/'Idumeja' and 'Anni'/'Dziugiai'). Coefficient of regression (b), mean yield over environments and deviation from regression line $\left(\mathrm{s}_{\mathrm{d}}{ }^{2}\right)$ were used as measures of stability and adaptability according to Eberhart and Russell (1966) and Finlay and Wilkinson (1963).

Genotypes with b larger than 1 were considered as responsive to favourable environments; genotypes with a high mean yield and $\mathrm{b}$ close to 1 - stable and with wide adaptation, and the ones with $\mathrm{b}$ lower than 1 - with better response to unfavourable environments. A low $\mathrm{s}_{\mathrm{d}}{ }^{2}$ value is presumed to indicate high stability. Most of the regression models were insignificant including all yield data, and hence barley data from location $\mathrm{O} 1$ were excluded from stability analysis. In that location, the low yield was caused by cockchafers (Melolontha melolontha) which damaged plant roots unequally in the trial.

Meteorological conditions were in general favourable for barley development in both years. Mean air temperature in the vegetation period surpassed the long term average by 2.6 and $2.4{ }^{\circ} \mathrm{C}$ in 2010 and 2011, respectively, resulting in early maturity. The amount of rainfall was $143 \%$ of the long-term average in 2010, which promoted lodging in con- ventional locations; in 2011, precipitation was close to average $(93 \%)$.

During the autumn/winter period in both years, weather conditions were not favourable for wheat wintering. High infection of snow mould influenced negatively the winter wheat grain yield. During the growing season, air temperature and soil moisture content was sufficient for wheat development.

\section{RESULTS}

Spring barley. Grain yield. Effect of location on grain yield was significant in both years, but effect of genotype - only for the group derived from 'Anni' and 'Dziugiai' in $2010(P<0.01)$. Yield data for 'Primus'/'Idumeja' group is provided in Table 4 and for the 'Anni'/'Dziugiai'group in Table 5.

Average yield in location C1 was $3.23 \mathrm{t} \mathrm{ha}^{-1}$ (2010) and $3.71 \mathrm{t} \mathrm{ha}^{-1}$ (2011). Yield above highest yielding parent with no significant differences occurred for mixtures in five cases, for population 1 in 2011 and for line 3 in 2010.

In location C2 the material yielded on average $4.24 \mathrm{t} \mathrm{ha}^{-1}$ and $4.75 \mathrm{t} \mathrm{ha}^{-1}$ in 2010 and 2011, respectively. Nonsignificant increase for highest yielding parent was only for pure lines of the 'Primus'/'Idumeja' group in two cases.

Table 4

GRAIN YIELD OF BARLEY VARIETIES 'PRIMUS', 'IDUMEJA' AND RELATED GENOTYPES, $\mathrm{t}^{\mathrm{h}}{ }^{-1}$

\begin{tabular}{|c|c|c|c|c|c|c|c|c|}
\hline \multirow[t]{2}{*}{ Year } & \multirow[t]{2}{*}{ Location } & \multicolumn{7}{|c|}{ Genotype } \\
\hline & & 'Primus' & 'Idumeja' & Line 1 & Line 2 & Mixture 2 & Popula- tion 1 & Mixture 3 \\
\hline \multirow[t]{4}{*}{2010} & $\mathrm{C} 1$ & $2.45^{\mathrm{c}}$ & $3.44^{\mathrm{ab}}$ & $3.34^{\mathrm{ab}}$ & $3.07^{\mathrm{bc}}$ & $3.88^{\mathrm{a}}$ & $3.34^{\mathrm{ab}}$ & $3.04^{\mathrm{bc}}$ \\
\hline & $\mathrm{C} 2$ & $3.68^{\mathrm{b}}$ & $4.23^{\mathrm{ab}}$ & $4.57^{\mathrm{a}}$ & $4.08^{\mathrm{ab}}$ & $3.84^{\mathrm{ab}}$ & $4.15^{\mathrm{ab}}$ & $4.21^{\mathrm{ab}}$ \\
\hline & $\mathrm{O} 1$ & 2.69 & 2.79 & 2.80 & 2.70 & 3.12 & 2.95 & 2.58 \\
\hline & $\mathrm{O} 2$ & 3.55 & 3.22 & 3.97 & 3.65 & 3.50 & 3.79 & 3.56 \\
\hline \multirow{3}{*}{2011} & $\mathrm{C} 2$ & 4.33 & 4.63 & 4.77 & 4.64 & 4.62 & 4.38 & 4.28 \\
\hline & $\mathrm{O} 1$ & 2.71 & 3.26 & 3.14 & 2.80 & 2.96 & 2.92 & 3.39 \\
\hline & $\mathrm{O} 2$ & 1.06 & 1.27 & 1.43 & 0.81 & 1.34 & 0.83 & 1.21 \\
\hline
\end{tabular}

a,b,c - values marked with different letters are significantly different within a row $(P<0.05)$.

GRAIN YIELD OF BARLEY VARIETIES 'ANNI', 'DZIUGIAI' AND RELATED GENOTYPES, $\mathrm{t} \mathrm{ha}^{-1}$

\begin{tabular}{|c|c|c|c|c|c|c|c|c|c|c|}
\hline \multirow[t]{2}{*}{ Year } & \multirow[t]{2}{*}{ Location } & \multicolumn{9}{|c|}{ Genotype } \\
\hline & & 'Anni' & 'Dziugiai' & Line 3 & Line 4 & Line 5 & Mixture 1 & Mixture 2 & $\begin{array}{c}\text { Popula- } \\
\text { tion } 2\end{array}$ & Mixture 4 \\
\hline \multirow[t]{4}{*}{2010} & $\mathrm{C} 1$ & $3.76^{\mathrm{ab}}$ & $3.13^{\mathrm{c}}$ & $4.02^{\mathrm{a}}$ & $3.45^{\mathrm{abc}}$ & $3.74^{\mathrm{ab}}$ & $4.00^{\mathrm{a}}$ & $3.88^{\mathrm{ab}}$ & $3.68^{\mathrm{abc}}$ & $3.32^{\mathrm{bc}}$ \\
\hline & $\mathrm{C} 2$ & $4.80^{\mathrm{a}}$ & $3.69^{c}$ & $4.59^{\mathrm{ab}}$ & $4.65^{\mathrm{ab}}$ & $4.48^{\mathrm{ab}}$ & $4.52^{\mathrm{ab}}$ & $3.84^{\mathrm{c}}$ & $4.48^{\mathrm{ab}}$ & $4.41^{\mathrm{abc}}$ \\
\hline & $\mathrm{O} 1$ & $2.79^{\mathrm{b}}$ & $2.92^{\mathrm{b}}$ & $3.32^{\mathrm{ab}}$ & $3.06^{\mathrm{ab}}$ & $3.57^{\mathrm{a}}$ & $3.36^{\mathrm{ab}}$ & $3.12^{\mathrm{ab}}$ & $3.10^{\mathrm{ab}}$ & $2.77^{\mathrm{b}}$ \\
\hline & $\mathrm{O} 2$ & $3.80^{\mathrm{ab}}$ & $3.31^{\mathrm{b}}$ & $3.98^{\mathrm{a}}$ & $3.71^{\mathrm{ab}}$ & $3.71^{\mathrm{ab}}$ & $3.74^{\mathrm{ab}}$ & $3.50^{\mathrm{ab}}$ & $3.73^{\mathrm{ab}}$ & $3.24^{\mathrm{b}}$ \\
\hline \multirow[t]{3}{*}{2011} & $\mathrm{C} 1$ & 4.05 & 3.69 & 3.77 & 4.00 & 4.00 & 3.94 & 3.49 & 3.84 & 3.75 \\
\hline & $\mathrm{C} 2$ & $5.23^{\mathrm{a}}$ & $4.57^{\mathrm{ab}}$ & $4.43^{\mathrm{b}}$ & $4.62^{\mathrm{ab}}$ & $4.72^{\mathrm{ab}}$ & $5.23^{\mathrm{a}}$ & $4.62^{\mathrm{ab}}$ & $4.50^{\mathrm{b}}$ & $4.65^{\mathrm{ab}}$ \\
\hline & $\mathrm{O} 1$ & 3.56 & 3.12 & 3.68 & 3.41 & 3.90 & 3.53 & 2.96 & 3.25 & 3.44 \\
\hline
\end{tabular}

a,b,c - values marked with different letters are significantly different within a row $(P<0.05)$. 
Location $\mathrm{O} 1$ provided average yield of $3.07 \mathrm{t} \mathrm{ha}^{-1}$ in 2010 and $3.30 \mathrm{t} \mathrm{ha}^{-1}$ in 2011. Significant differences were only in 2010 for the 'Anni'/'Dziugiai' group, where line 5 surpassed both parents. Mixtures over yielded the highest yielding parent occurred in four cases, populations in two cases and lines in five cases (Table 7). Average yield in location $\mathrm{O} 2$ was $3.60 \mathrm{t} \mathrm{ha}^{-1}$ in 2010 and $1.39 \mathrm{t} \mathrm{ha}^{-1}$ in 2011 due to incidence of cockchafers.

Line 3 significantly surpassed the yield of the lower yielding parent 'Dziugiai' and non-significantly of the higher yielding parent 'Anni'. Overall, lines provided higher yield in comparison to better yielding parent in five cases; population 1 yielded above and below the parent range in 2010 and 2011, respectively (differences not significant).

Yield stability. Among the material with yield above average, comparatively stable yield was found for line 4, but lines 3 and 5 showed specific adaptation to unfavourable environments (Table 6). Mixture 1 provided the highest mean yield between all environments and was slightly better adapted to favourable environments, and population 2 to unfavourable ones.

Grain quality. In all locations and both years the effect of environment on grain quality parameters was significant and the effect of genotype was significant with the exception of volume weight in 2010 and crude protein in 2011 for the 'Primus'/'Idumeja' group $(P<0.05)$.

Crude protein content in conventional locations was on average $155 \mathrm{~g} \mathrm{~kg}^{-1}$ in 2010 and $135 \mathrm{~g} \mathrm{~kg}^{-1}$ in 2011; in organic locations - $137 \mathrm{~g} \mathrm{~kg}^{-1}$ and $127 \mathrm{~g} \mathrm{~kg}^{-1}$, respectively

In general, protein content of pure lines, mixtures and populations in all locations varied within the range of parental varieties. Only a few accessions had insignificantly higher or lower protein content in comparison to the range between the respective parents (Table 7). Protein content of population 1 in 2011 in locations $\mathrm{C} 1, \mathrm{O} 1$ and $\mathrm{O} 2$ surpassed that of parents, although the differences were not significant (Fig. $1)$.

For mixture 1 a tendency was observed in both years in locations $\mathrm{O} 1$ and $\mathrm{C} 2$ to have protein content on average 5 $\mathrm{g} \mathrm{kg}^{-1}$ lower in the two pure lines compared to components of the mixture (difference not significant).

Grain starch content in conventional locations was on average $598 \mathrm{~g} \mathrm{~kg}^{-1}$ in 2010 and $605 \mathrm{~g} \mathrm{~kg}^{-1}$ in 2011; in organic locations it was $611 \mathrm{~g} \mathrm{~kg}^{-1}$ and $610 \mathrm{~g} \mathrm{~kg}^{-1}$, respectively. Only mixture 2 in $\mathrm{O} 2$ in 2011 had starch content significantly higher than in the parent of component line 2 'Primus' and equal to parent of component line 5 'Dziugiai'. The values were above the range of parents for mixture 3 and breeding lines only under organic growing conditions, although negative tendencies were observed as well (Table 7).

Grain volume weight was on average $631 \mathrm{~g} \mathrm{~L}^{-1}$ in 2010 and $690 \mathrm{~g} \mathrm{~L}^{-1}$ in 2011 under conventional farming and $662 \mathrm{~g} \mathrm{~L}^{-1}$ in 2010 and $678 \mathrm{~g} \mathrm{~L}^{-1}$ in 2011 under organic farming.
Table 6

YIELD STABILITY AND ADAPTABILITY PARAMETERS OF BARLEY MATERIAL

\begin{tabular}{l|c|c|c|c}
\hline \multicolumn{1}{c|}{ Genotype } & $\begin{array}{c}\text { Mean yield } \\
\mathrm{t} \mathrm{ha}^{-1}\end{array}$ & $\begin{array}{c}\text { Coefficient of } \\
\text { regression (b) })\end{array}$ & $\begin{array}{c}\text { Deviation } \\
\text { from regres- } \\
\text { sion }\left(\mathrm{s}^{2} \mathrm{~d}\right)\end{array}$ & $P$-value \\
\hline Mixture 1 & $4.05^{* \wedge}$ & 1.06 & 0.02 & 0.00 \\
Line 5 & $4.02^{* \wedge}$ & $0.70^{\vee}$ & 0.01 & 0.00 \\
'Anni' & $4.00^{* \wedge}$ & 1.36 & 0.02 & 4.01 \\
Line 3 & $3.97^{* \wedge}$ & 0.66 & 0.04 & 0.00 \\
Line 4 & $3.84^{\wedge}$ & 1.01 & 0.02 & 0.00 \\
Population 2 & $3.80^{\wedge}$ & 0.89 & 0.02 & 0.00 \\
Line 1 & $3.72^{2}$ & 1.25 & 0.01 & 2.43 \\
Mixture 4 & 3.65 & 1.11 & 0.02 & 0.00 \\
Mixture 2 & 3.63 & 0.81 & 0.09 & 0.01 \\
Population 1 & 3.52 & 0.95 & 0.01 & 5.85 \\
'Idumeja' & 3.50 & 1.11 & 0.06 & 0.00 \\
'Dziugiai' & 3.49 & 0.89 & 0.04 & 0.00 \\
Mixture 3 & 3.45 & 1.01 & 0.04 & 0.00 \\
Line 2 & 3.44 & 1.20 & 0.01 & 2.61 \\
'Primus' & 3.19 & 1.04 & 0.08 & 0.00 \\
Average & 3.67 & & & \\
& & & &
\end{tabular}

*significantly higher than average $(P<0.05)$; ^ higher than average without significant difference; $\vee$ coefficient of regression significantly different from 1

Lower volume weight compared to parents was found in several cases for all kinds of accessions (Table 7) of the 'Anni'/'Dziugiai' group. A tendency for line 3 was to have lower volume weight than the parents in all locations except O1 in 2010 (differences significant in three cases). Population 2 had volume weight below the range of parents in conventional locations.

Average TGW values were 40.4 and $51.3 \mathrm{~g}$ under conventional environments and 43.5 and $44.8 \mathrm{~g}$ under organic environments in 2010 and 2011, respectively. Pure lines of the 'Anni'/'Dziugiai' group significantly surpassed parents in several cases, especially line 5 with the exception of conventional locations in 2010 only. Parents 'Anni' and 'Dziugiai' were significantly exceeded by mixture 2, which consisted of lines from both cross combinations; in three cases there was a tendency to exceed the other two parents.

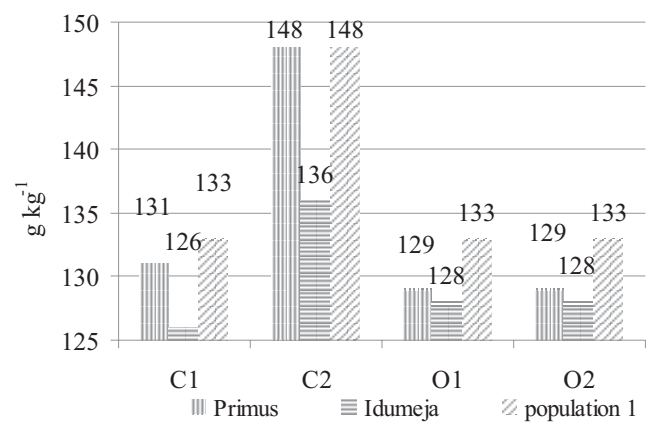

Fig. 1. Crude protein in grain of barley population 1 in comparison with parents in 2011 
NUMBER OF ACCESSIONS WITH TRAIT VALUES OUTSIDE THE RANGE OF PARENTS/COMPONENTS

\begin{tabular}{|c|c|c|c|c|c|c|c|c|c|c|c|c|c|}
\hline \multirow[t]{2}{*}{ Traits } & \multirow[t]{2}{*}{ Year } & \multicolumn{4}{|c|}{ Mixtures $(n=4)$} & \multicolumn{4}{|c|}{ Populations $(\mathrm{n}=2)$} & \multicolumn{4}{|c|}{ Lines $(n=5)$} \\
\hline & & $\mathrm{C} 1$ & $\mathrm{C} 2$ & $\mathrm{O} 1$ & $\mathrm{O} 2$ & $\mathrm{C} 1$ & $\mathrm{C} 2$ & $\mathrm{O} 1$ & $\mathrm{O} 2$ & $\mathrm{C} 1$ & $\mathrm{C} 2$ & $\mathrm{O} 1$ & $\mathrm{O} 2$ \\
\hline \multirow[t]{2}{*}{ Grain yield } & 2010 & +2 & - & $\begin{array}{l}+2 \\
-1\end{array}$ & -1 & - & - & +2 & +1 & +1 & +1 & $\begin{array}{l}+2 \\
+1\end{array}$ & +3 \\
\hline & 2011 & $\begin{array}{l}+2 \\
-1 \\
\end{array}$ & - & $\begin{array}{l}+1 \\
-1 \\
\end{array}$ & - & +1 & -1 & - & -1 & +2 & $\begin{array}{l}+1 \\
-1 \\
\end{array}$ & +2 & $\begin{array}{l}+2 \\
-1 \\
\end{array}$ \\
\hline \multirow{2}{*}{ Crude protein } & 2010 & - & - & - & -1 & - & - & - & - & - & - & -1 & - \\
\hline & 2011 & +1 & - & +1 & $\begin{array}{l}+1 \\
-2 \\
\end{array}$ & +1 & - & +1 & +2 & - & -3 & $\begin{array}{l}+1 \\
-1 \\
\end{array}$ & $\begin{array}{l}+1 \\
-2 \\
\end{array}$ \\
\hline \multirow[t]{2}{*}{ Starch } & 2010 & - & - & -1 & -1 & - & - & - & -1 & - & - & +2 & $\begin{array}{l}+1 \\
-1\end{array}$ \\
\hline & 2011 & - & - & -1 & $\begin{array}{l}+1 \\
-2 \\
\end{array}$ & -1 & -1 & -1 & -1 & - & - & -2 & $\begin{array}{l}+3 \\
-1 \\
\end{array}$ \\
\hline \multirow[t]{2}{*}{ Volume weight } & 2010 & -1 & $-1,-1$ & - & -1 & -1 & -1 & - & - & $\begin{array}{c}+2 \\
-1,-2\end{array}$ & -2 & - & $\begin{array}{l}-1 \\
-1\end{array}$ \\
\hline & 2011 & $\begin{array}{l}+1 \\
-2 \\
\end{array}$ & $\begin{array}{l}-1 \\
-2 \\
\end{array}$ & - & - & -1 & -1 & - & - & $\begin{array}{l}+1 \\
-2 \\
\end{array}$ & $\begin{array}{l}-1 \\
-2 \\
\end{array}$ & -1 & $\begin{array}{l}+1 \\
-1 \\
\end{array}$ \\
\hline \multirow[t]{2}{*}{ TGW } & 2010 & $\begin{array}{l}+2 \\
+1\end{array}$ & - & $\begin{array}{l}+3 \\
-1\end{array}$ & - & - & - & $\begin{array}{l}+1 \\
-1\end{array}$ & - & +1 & - & $\begin{array}{l}+4 \\
+1\end{array}$ & $\begin{array}{l}+2 \\
+1\end{array}$ \\
\hline & 2011 & +2 & $\begin{array}{l}+3 \\
+1 \\
\end{array}$ & $\begin{array}{l}+2 \\
+1 \\
\end{array}$ & +2 & - & +2 & +2 & - & $\begin{array}{l}+4 \\
+1 \\
\end{array}$ & $\begin{array}{l}+3 \\
+2 \\
\end{array}$ & $\begin{array}{l}+3 \\
+2 \\
\end{array}$ & $\begin{array}{r}+1 \\
+1 \\
\end{array}$ \\
\hline \multirow[t]{2}{*}{$\begin{array}{l}\text { Infection with net } \\
\text { blotch }\end{array}$} & 2010 & $\begin{array}{l}-2 \\
-1\end{array}$ & - & - & - & $\begin{array}{l}-1 \\
-\mathbf{- 1}\end{array}$ & - & - & - & -4 & - & - & - \\
\hline & 2011 & -4 & - & +2 & +2 & -1 & - & +1 & +1 & $\begin{array}{l}+1 \\
-2 \\
\end{array}$ & - & +2 & $\begin{array}{l}+2 \\
+1 \\
\end{array}$ \\
\hline \multirow[t]{2}{*}{$\begin{array}{l}\text { Infection with pow- } \\
\text { dery mildew }\end{array}$} & 2010 & $\begin{array}{l}+2 \\
+1\end{array}$ & $\begin{array}{l}+2 \\
+1\end{array}$ & -1 & $\begin{array}{l}+3 \\
-1\end{array}$ & $\begin{array}{l}+1 \\
+1\end{array}$ & +2 & $\begin{array}{l}+1 \\
-1\end{array}$ & $\begin{array}{l}+1 \\
-1\end{array}$ & +4 & $\begin{array}{l}+2 \\
-2\end{array}$ & $\begin{array}{l}-2 \\
+3\end{array}$ & +2 \\
\hline & 2011 & +1 & +2 & -1 & - & +1 & +1 & +1 & - & $\begin{array}{l}+2 \\
-1 \\
\end{array}$ & $\begin{array}{l}+1 \\
-3 \\
\end{array}$ & $\begin{array}{l}+1 \\
-3 \\
\end{array}$ & - \\
\hline \multirow[t]{2}{*}{ Lodging } & 2010 & - & -1 & - & -1 & - & - & - & - & - & -2 & - & - \\
\hline & 2011 & - & $*$ & - & $*$ & - & $*$ & - & $*$ & - & $*$ & - & $*$ \\
\hline \multirow[t]{2}{*}{ Weed ground cover } & 2010 & $*$ & $*$ & $\begin{array}{l}+2 \\
-1\end{array}$ & $\begin{array}{c}+1,-1 \\
-\mathbf{1}\end{array}$ & $*$ & $*$ & -1 & -2 & $*$ & $*$ & $\begin{array}{l}-1 \\
+1\end{array}$ & -1 \\
\hline & 2011 & $*$ & $*$ & $\begin{array}{l}+1 \\
-1\end{array}$ & $\begin{array}{c}+3 \\
-1\end{array}$ & $*$ & $*$ & -1 & +2 & $*$ & $*$ & -4 & -4 \\
\hline
\end{tabular}

* Observation not made; difference significant for numbers in bold $(P<0.05)$; positive numbers - above and negative numbers - below the range of respective parents/components

Both populations surpassed TGW of parents insignificantly in locations $\mathrm{C} 2$ and $\mathrm{O} 1$ in 2011 (Table 7).

Infection with leaf diseases. The average level of net blotch under natural background was score 6.8. It ranged 6.0-8.0 under conventional locations and 5.5-8.0 under organic locations. 'Idumeja' and 'Anni' were the most susceptible parents. Disease scores were generally lower at locations C2 and $\mathrm{O} 1$ and higher at locations $\mathrm{C} 1$ and $\mathrm{O} 2$. Effect of genotype on infection with net blotch was significant $(P<0.05)$ with the exception of the 'Primus'/'Idumeja' group in C2 and $\mathrm{O} 1$ in 2011 and the 'Anni'/'Dziugiai' group in C2 and O2 in 2010. The effect of location was significant with the exception of the 'Primus'/'Idumeja' group in 2011. Mixture 2 had significantly lower infection compared to both pairs of parents in $\mathrm{C} 1$ location in 2010, but it was not significantly lower than for component lines of this mixture. Population 1 was significantly less infected than parents in location $\mathrm{C} 1$ in 2010 and population 2 showed a tendency to lower infection in $\mathrm{C} 1$ in both years. Higher infection compared to parents was observed for nearly all accessions of the 'Anni'/'Dziugiai' group under organic locations in 2011 (differences significant for line 4, mixture 2 and population 2 in O2). Overall, some advantages were found for all kinds of accessions in location $\mathrm{C} 1$ only, whereas in organic locations the infection level exceeded the range of parents in 2011 in several cases (Table 7).

The average infection level with powdery mildew was comparatively low: score 2.4 in 2010 and score. 9 in 2011. It ranged from $0-6.5$ under conventional conditions and $0-5.8$ under the organic ones. A tendency to lower infection with the disease was found in organic locations and for the 'Primus'/'Idumeja' group. The most susceptible parent was 'Dziugiai'. The effect of genotype on infection with powdery mildew was significant $(P<0.05)$ with the exception of $\mathrm{O} 1$ in 2011 for both groups and $\mathrm{O} 2$ in the same year for the 'Primus'/'Idumeja' group for which no signs of infec- 
tion were found. The effect of location was significant in both years. Significantly lower infection with mildew compared to parents was observed for line 1 and line 2 in location $\mathrm{O} 1$ in 2010.

Population 2 was significantly less infected than parents in O2 in 2010 and showed a tendency to lower infection under organic conditions while population 1 was more infected with mildew than the parents in all locations (differences significant in C1 2010 and C2 2011). Mixture 2 consisting of breeding lines originating from both cross combinations had higher infection in comparison to parents 'Primus' and 'Idumeja' under conventional locations and in O2 in 2010 and also in comparison to parents 'Anni' and 'Dziugiai' in conventional locations in 2010 (majority of differences significant). In general, for mixtures and populations, some advantages were found under organic locations but no advantages under conventional locations.

Lodging. Average lodging scores in conventional locations were 5.0 and 8.3 and in organic locations - 7.5 and 8.0 in 2010 and 2011, respectively. Lodging for most accessions varied between the scores of parents; no advantages were found, only a few cases mixtures and lines lodged more than the respective parents (Table 7).

Weed ground cover. Weed ground cover in stem elongation stage in location O1 was $39-65 \%$ in 2010 and $6-15 \%$ in 2011; in O2 it was 29-53\% and 7-17\%, respectively. Effect of genotype on weed ground cover was significant only in location $\mathrm{O} 2$ in 2010, where the average score was the highest $(39 \%)$ : significantly lower amount of weeds in comparison to parents 'Primus' and 'Idumeja' was observed for mixture 3 consisting of both varieties. The short stem variety 'Anni' with a low development rate had the highest weed ground cover (Fig. 2). Weed ground cover of mixture 3 was below that of the parents also in O1 in 2010, but it exceeded that of parents in 2011. For populations and lines insignificant advantages were observed in several cases (Table 7).

Winter wheat. Resistance to abiotic stress-resistance to snow mould and winter hardiness. In local wheat breeding programmes parental varieties originating from different countries (Germany, Poland, USA, Latvia, and Byelorussia) were used. The varieties were bred mostly for conventional system, with high productivity, grain quality suitable for food but with different winter hardiness.

In Latvian agroclimatical conditions during 2009-2011 the serious limiting factors for wheat yield were low winter hardiness and high infection level with snow mould in both sites (Priekuli and Stende) and both growing systems. In the years of investigations wheat genotypes were infected with snow mould (Fusarium nivale (Fr.) Ces) at a score of 3.6-9.0 (Table 8). A lower infection level of snow mould was observed for parental varieties 'Krista' (LV) and 'Bilina' (BY), 98-131(LV) in both conditions.

Winter hardiness of wheat populations depended on parent resistance to abiotic and biotic stress. The best results were

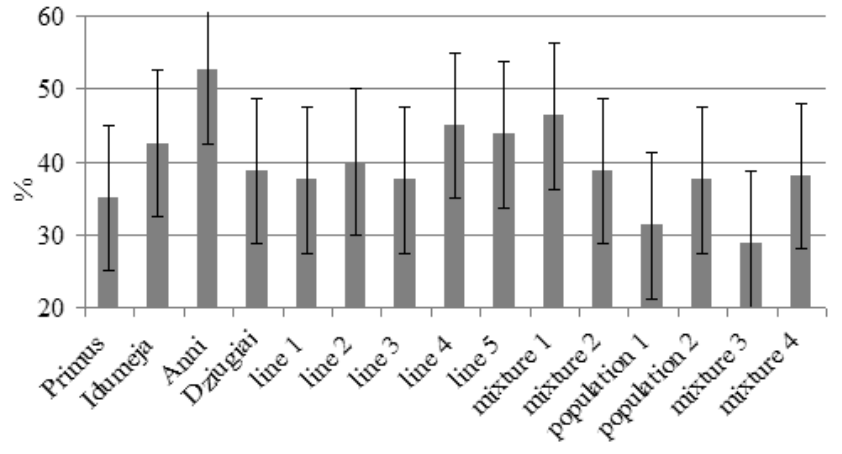

Fig. 2. Weed ground cover in barley stem elongation stage in location $\mathrm{O} 2$ in 2010 .

shown for populations from combinations where both or one of parents was characterised by good adaptability to local conditions. In all environments populations 08-6 (As-

Table 8

WINTER WHEAT POPULATIONS AND PARENTAL VARIETIES INFECTION LEVEL (1-9) WITH SNOW MOULD (Fusarium nivale (FR.) CES, 2010/2011

\begin{tabular}{|c|c|c|c|c|c|}
\hline \multirow[t]{2}{*}{ Genotype } & \multirow{2}{*}{$\begin{array}{l}\text { Denomina- } \\
\text { tion }\end{array}$} & \multirow{2}{*}{$\begin{array}{c}\text { Mean win- } \\
\text { ter hardi- } \\
\text { ness, } \\
1-9\end{array}$} & \multicolumn{2}{|c|}{ Organic field } & \multirow{2}{*}{$\begin{array}{c}\text { Conven- } \\
\text { tional field } \\
\text { (Stende) }\end{array}$} \\
\hline & & & Stende & Priekul̦i & \\
\hline$q$ & 'Haldor' & 3.2 & 8.7 & - & 7.9 \\
\hline$\hat{\delta}$ & 66 & 3.5 & 8.1 & - & 7.5 \\
\hline population & $08-4$ & 5.2 & 8.2 & 7.3 & 8.0 \\
\hline q & 'Ibis’' & 5.7 & 7.3 & - & 7.5 \\
\hline$\hat{\sigma}$ & 'Dekan' & 3.3 & 8.8 & - & 8.5 \\
\hline population & 08-5 & 5.4 & 8.7 & 8.1 & 7.7 \\
\hline$q$ & 'Astron' & 5.9 & 7.9 & - & 8.0 \\
\hline$\hat{\sigma}$ & 'Bill' & 6.8 & 8.7 & - & 7.0 \\
\hline population & $08-6$ & 5.2 & 6.3 & 7.2 & 5.1 \\
\hline q & 'Bilina' & 7.3 & 5.0 & - & 6.3 \\
\hline$\hat{\sigma}$ & $\mathrm{KOC} / 2520 / 97$ & 3.2 & 8.9 & - & 9.0 \\
\hline population & $08-7$ & 5.8 & 7.8 & 7.2 & 6.9 \\
\hline$q$ & 'Cubus' & 3.2 & 9.0 & - & 9.0 \\
\hline$\hat{\sigma}$ & $98-131$ & 7.8 & 5.4 & - & 5.7 \\
\hline population & 08-9 & 7.3 & 7.3 & 6.4 & 5.6 \\
\hline$q$ & A.St.2519 & 6.3 & 7.0 & - & 8.3 \\
\hline$\hat{\sigma}$ & 'Krista' & 7.9 & 3.6 & - & 5.2 \\
\hline population & 08-13 & 6.3 & 7.9 & 7.6 & 7.4 \\
\hline q & NIC 4680A & 3.7 & 8.3 & - & 8.0 \\
\hline$\hat{\sigma}$ & 'Redford' & 1.5 & 9.0 & - & 9.0 \\
\hline population & $08-28$ & 5.3 & 7.4 & 8.0 & 7.0 \\
\hline \multicolumn{6}{|c|}{ Winter wheat populations } \\
\hline & Mean & 5.78 & 7.7 & 7.4 & 6.8 \\
\hline & Max. & 7.3 & 8.7 & 8.1 & 8.0 \\
\hline & Min. & 5.2 & 6.3 & 6.4 & 5.1 \\
\hline \multicolumn{6}{|c|}{ Winter wheat parental varieties } \\
\hline & Mean & 5.22 & 7.6 & - & 6,5 \\
\hline & Max. & 7.9 & 9.0 & - & 9.0 \\
\hline & Min. & 1.5 & 3.6 & - & 5.2 \\
\hline
\end{tabular}


tron/Bill) (5.1-7.2 scores), 08-9 (Cubus/98-131) (5.6-7.3) and 08-13 A.St.2519/ Krista (7.4-7.9) were less infected with snow mould (Table 8). Winter hardiness of those populations was scored 7.9-5.9.

Grain yield and stability. Grain yield of populations varied between 1.32-6.54 $\mathrm{t} \mathrm{ha}^{-1}$ under organic conditions, and 1.71-6.58 t ha ${ }^{-1}$ in conventional conditions (Table 9). Productivity of parental varieties was between 1.32-5.41 $\mathrm{t} \mathrm{ha}^{-1}$ under organic conditions, and between $2.00-6.89 \mathrm{t} \mathrm{ha}^{-1}$ under the conventional growing system. Productivity of genotypes was tightly linked with the snow mould infection level and winter hardiness.

ANOVA showed that the grain yield for winter wheat populations and parental varieties was significantly $(P<0.01)$ influenced by all three main factors (genotype, year and location) and their interaction: effect of genotype $\sigma^{2}=11 \%$, environment $\sigma^{2}=50 \%$, and interaction of these factors $\sigma^{2}=$ $23.5 \%$. Grain yield of parental varieties significantly differed in all locations. ANOVA confirmed that the grain yield was mainly determined by genotype $\sigma^{2}=51 \%$, environment $\sigma^{2}=20 \%$ and $\mathrm{G} \times \mathrm{E} \sigma^{2}=17 \%$.

The grain yield of six wheat populations was significant lower than that of parental varieties under organic conditions. Only two populations 08-9 Cubus/98-131 (2.32 $\mathrm{t} \mathrm{ha} \mathrm{h}^{-1}$ ), 08-5 Ibis/Dekan (2.68 $\mathrm{t} \mathrm{ha}^{-1}$ ) had insignificant higher yield in comparison with one parent.

Under conventional conditions significant higher yield compared to the average yield of populations was obtained from populations 08-7 Bilina/KOC/2520/97 and 08-13 A.St.2519/Krista. A tendency for higher yield in conventional conditions was shown for wheat population 08-6 Astron/Bil. Three populations had yield lower than the parents, but productivity of three populations insignificantly exceeded that of the parents. Only two populations 08-6 and 08-9 had higher yield than both parental varieties.

Population 08-6 Astron/Bill had insignificant higher yield in comparison with the average population yield under conventional conditions, but not a stable level under unfavourable circumstances (Table 10).

Regarding yield stability parameters, the majority of regression models were not significant (Table 10). However, populations with adaptability to unfavourable environments (08-6 and 08-9), with wide adaptation (08-12) and a tendency to adaptation to favourable environments (08-7 and 08-13) could be identified.

Grain quality. TGW values were closely associated with genotype in both years and unimportantly influenced by location. Average TGW for populations was $47.82 \mathrm{~g}$ in organic conditions and $49.49 \mathrm{~g}$ in the conventional field; for parental varieties respectively $47.32 \mathrm{~g}$ and $49.31 \mathrm{~g}$ (Table 11). Populations showed insignificant tendency to have highest TGW compared by parental varieties in both farming systems sites.
Table 9

GRAIN YIELD T HA ${ }^{-1}$ OF WINTER WHEAT POPULATIONS IN DIFFERENT GROWING CONDITIONS, 2010-2011

\begin{tabular}{l|c|c|c|c|c}
\hline \multirow{2}{*}{ Populations } & \multicolumn{2}{|c|}{2010} & \multicolumn{3}{c}{2011} \\
\cline { 2 - 6 } & ST B & ST C & ST B & ST C & PR B \\
\hline $08-4$ & 1.82 & 4.83 & 2.05 & 2.71 & 1.31 \\
$08-5$ & 1.97 & 2.40 & 3.43 & 4.53 & 1.39 \\
$08-6$ & 2.44 & 5.27 & 3.83 & 6.52 & 1.58 \\
$08-7$ & 2.17 & 6.47 & 3.03 & 5.73 & 2.26 \\
$08-9$ & 1.84 & 3.70 & 2.82 & 5.42 & 1.52 \\
$08-12$ & 1.60 & 4.63 & 2.74 & 5.73 & 1.75 \\
$08-13$ & 1.98 & 5.80 & 3.40 & 6.54 & 2.13 \\
$08-23$ & 2.06 & 4.27 & 1.50 & 2.73 & 1.92 \\
$08-27$ & 2.07 & 6.63 & 2.71 & 2.83 & 1.73 \\
$08-28$ & 2.58 & 4.37 & 3,10 & 1.41 & 1.57 \\
Average & 2.12 & 4.9 & 2.81 & 4.40 & 1.70
\end{tabular}

*ST- Stende *PR-Priekul̦i

The content of crude protein in wheat grain is closely connected with growing conditions and nutrient uptake $(\mathrm{N})$, and less affected by genotype. In organic growing conditions in both sites the crude protein content of populations and parental varieties was lower compare to that in the conventional field. In $\mathrm{O}$ field average crude protein content of populations was lower than that of parental varieties, except for population 08-('Haldor'/2936/96) - $122 \mathrm{~g} \mathrm{~kg}^{-1}$. This population showed a tendency to have higher protein content than for parental varieties and grain was suitable for food. Average crude protein content for parental variety 'Haldor' in both years was $101 \mathrm{~g} \mathrm{~kg}^{-1}$ and 2936/96 - 96 $\mathrm{g} \mathrm{kg}^{-1}$.

In conventional conditions the average content of the crude protein of populations was lower, $-156 \mathrm{~g} \mathrm{~kg}^{-1}$, in comparison with parental varieties, $-162 \mathrm{~g} \mathrm{~kg}^{-1}$, (Table 10), but the grain quality of all genotypes was suitable for food.

The content of gluten was positively correlated with crude protein $\left(\mathrm{r}=0.61 P_{0.05}=0.48\right)$ and also influenced by associated with the growing environment and nutrient uptake, but was less affected by genotype. The average gluten content of populations was lower in all locations when compared to that of parental varieties. In $\mathrm{O}$ fields the average content of gluten of populations was $172 \mathrm{~g} \mathrm{~kg}^{-1}$, and parental varieties $189 \mathrm{~g} \mathrm{~kg}^{-1}$, in $\mathrm{C}$ growing conditions $-277 \mathrm{~g}$ $\mathrm{kg}^{-1}$ and $292 \mathrm{~g} \mathrm{~kg}^{-1}$ (Table 11).

The gluten quality Sedimentation Value or Zeleny index also was closely connected with crude protein content. A significant positive, close correlation $\mathrm{r}=0.71 P_{0.05}=0.52$ was found between these variables. Also, a significant positive, close correlation $\left(\mathrm{r}=0.88 P_{0.05}=0.52\right)$ was found between Zeleny index and gluten content. Value of the Zeleny index of all genotypes was lower in $\mathrm{O}$ conditions than in the $\mathrm{C}$ field. In $\mathrm{O}$ conditions the average value of Zeleny index was $30.6 \mathrm{~mL}$ for populations and $34.4 \mathrm{~mL}$ for parental varieties, and in $\mathrm{C}$, respectively, $56.6 \mathrm{~mL}$ and $54.9 \mathrm{~mL}$ (Table 
GRAIN YIELD AND STABILITY PARAMETERS OF WINTER WHEAT POPULATIONS AND PARENTS, 2010/2011

\begin{tabular}{|c|c|c|c|c|c|c|}
\hline \multirow[t]{2}{*}{ Genotype } & \multicolumn{2}{|c|}{ Mean grain yield $\mathrm{t} \mathrm{ha}^{-1}$} & \multirow{2}{*}{$\begin{array}{c}\text { Mean grain yield in all grow- } \\
\text { ing conditions } \\
\mathrm{t} \mathrm{ha}^{-1}\end{array}$} & \multirow{2}{*}{$\begin{array}{l}\text { Coefficient } \\
\text { of regression } \\
\text { (b) }\end{array}$} & \multirow{2}{*}{$\begin{array}{c}\text { Deviation } \\
\text { from regres- } \\
\operatorname{sion}\left(\mathrm{s}_{\mathrm{d}}{ }^{2}\right) \\
\end{array}$} & \multirow[t]{2}{*}{$P$-value } \\
\hline & $\mathrm{O}$ & $\mathrm{C}$ & & & & \\
\hline 08-4 Haldor/66 & 1.91 & 3.76 & 2.83 & 2.03 & 0.80 & 0.28 \\
\hline † Haldor & 3.23 & 4.87 & 4.05 & - & - & - \\
\hline$\delta 66$ & 2.77 & 2.00 & 2.38 & - & - & - \\
\hline 08-5 Ibis/Dekan & 2.68 & 3.45 & 3.06 & 0.52 & 1.87 & 0.78 \\
\hline O Ibis & 4.07 & 6.53 & 5.30 & - & - & - \\
\hline ô Dekan & 2.00 & 3.50 & 2.75 & - & - & - \\
\hline 08-6 Astron/Bill & $\wedge 3.12$ & 5.88 & $\wedge 4.50$ & 0.73 & 0.02 & 0.02 \\
\hline † Astron & 3.73 & 4.83 & 4.28 & - & - & - \\
\hline ổ Bill & 4.37 & 5.00 & 4.68 & - & - & - \\
\hline \multicolumn{7}{|l|}{ 08-7 Bilina/KOC/2520/97 } \\
\hline & 2.58 & $* 6.58$ & $\wedge 4.58$ & 1.62 & 0.33 & 0.00 \\
\hline$\widehat{\delta} \mathrm{KOC} / 2520 / 97$ & 3.65 & 6.89 & 5.27 & - & - & - \\
\hline 08-9 Cubus/98-131 & 2.32 & 4.55 & 3.43 & 0.95 & 0.84 & 0.00 \\
\hline qCubus & 2.07 & 2.02 & 2.04 & - & - & - \\
\hline ठ̀98-131 & 3.72 & 1.72 & 2.72 & - & - & - \\
\hline 08-12 Haldor/14(ASV) & 2.67 & 3.76 & 3.21 & 1.19 & 0.56 & 0.02 \\
\hline O Haldor & 3.23 & 4.87 & 4.05 & - & - & - \\
\hline$\delta_{14}$ & 2.87 & 3.42 & 3.14 & - & - & \\
\hline \multicolumn{7}{|l|}{ 08-13 A.St.2519/Krista } \\
\hline & 2.69 & *6.15 & $\wedge 4.42$ & 1.41 & 0.44 & 0.01 \\
\hline †A.St.2519 & 3.27 & 3.20 & 3.23 & - & - & - \\
\hline$\widehat{\delta}$ Krista & 4.41 & 6.71 & 6.06 & - & - & - \\
\hline \multicolumn{7}{|c|}{ 08-23 Nic99-3946B/Verbena/Krista } \\
\hline$\delta$ Krista & 4.41 & 6.71 & 6.06 & - & - & - \\
\hline \multicolumn{7}{|c|}{ Winter wheat populations } \\
\hline Mean & 2.50 & 4.63 & 3.31 & & & \\
\hline Min. & 1.91 & 2.98 & 2.11 & & & \\
\hline Max. & 3.12 & 6.58 & 4.58 & & & \\
\hline \multicolumn{7}{|c|}{ Winter wheat parental varieties } \\
\hline Mean & 3.45 & 4.56 & 4.07 & & & \\
\hline Min. & 2.00 & 2.00 & 2.04 & & & \\
\hline Max. & 4.41 & 6.89 & 6.06 & & & \\
\hline
\end{tabular}

*significantly higher than average of populations $(P<0.05)$; ${ }^{\wedge}$ higher than average of populations without significant differences; ${ }^{\vee}$ coefficient of regression significantly different from 1

$\subsetneq$ female parent, $\widehat{\jmath}$ male parent

11). Populations showed insignificant tendency to have highest Sedimentation Value, compared to that of parental varieties in conventional conditions.

\section{DISCUSSION}

Barley parental varieties and breeding lines were selected for the experiment with emphasis on differences in traits important for growing under organic farming and mostly in relation to competitive ability with weeds (early development rate, maturity time, plant growth habit) and grain vol- ume weight and TGW ('Primus', 'Idumeja'). Consequently, the largest gain of mixtures, populations and lines in comparison to parents in pure stand can be expected in respect to weed ground cover and the grain quality traits mentioned. The results show only one case of significant reduction of weed ground cover for one variety mixture which occurred in the organic field with comparatively highest weed amount. In addition several desirable tendencies were observed for pure lines, populations and mixtures. No significant advantages regarding volume weight were found, whereas significantly higher TGW was observed only for 
AVERAGE, MINIMUM AND MAXIMUM OF GRAIN QUALITY TRAITS FOR WINTER WHEAT POPULATIONS AND PARENTAL VARIETIES, 2010/2011

\begin{tabular}{|c|c|c|c|c|}
\hline \multicolumn{3}{|c|}{ Populations } & \multicolumn{2}{|c|}{$\oint \hat{\delta}$ Pariental varieties } \\
\hline & $\mathrm{O}$ & $\mathrm{C}$ & $\mathrm{O}$ & $\mathrm{C}$ \\
\hline \multicolumn{5}{|c|}{ TGW, g } \\
\hline Mean. & 47.82 & 49.49 & 47.32 & 49.31 \\
\hline Min. & 45.61 & 45.86 & 45.41 & 46.36 \\
\hline Max. & 53.04 & 53.86 & 49.81 & 57.55 \\
\hline \multicolumn{5}{|c|}{ Crude protein content, $\mathrm{g} \mathrm{kg}^{-1}$} \\
\hline Mean. & 102 & 156 & 117 & 162 \\
\hline Min. & 94 & 151 & 103 & 137 \\
\hline Max. & 111 & 163 & 130 & 184 \\
\hline \multicolumn{5}{|c|}{ Gluten content, $\mathrm{g} \mathrm{kg}^{-1}$} \\
\hline Mean. & 172 & 277 & 189 & 292 \\
\hline Min. & 168 & 251 & 173 & 251 \\
\hline Max. & 176 & 313 & 227 & 336 \\
\hline \multicolumn{5}{|c|}{ Sedimentation Value (Zeleny index), mL } \\
\hline Mean. & 30.6 & 56.6 & 34.6 & 54.9 \\
\hline Min. & 29.3 & 53.7 & 29.1 & 52.3 \\
\hline Max. & 32.8 & 61.1 & 38.6 & 58.7 \\
\hline
\end{tabular}

pure lines, indicating that breeder's selection for this trait was more effective than natural selection. The same can be concluded regarding grain yield: the only case of significant yield gain over parental varieties was for breeding line 5 under organic $\mathrm{O} 1$ management. Yield of this line was close to the better yielding parent 'Anni' under $\mathrm{C} 1$ and organic environments in other cases, and the regression coefficient was significantly below 1 , indicating adaptability to unfavourable environments. Since the selection of lines was made with the aim to create varieties for organic growing conditions, line 5 can be considered as a breeder's success.

It has been experimentally shown that variety mixtures can be an alternative to growing pure varieties; there are distinctive epidemiological and ecological factors leading to noticeable decrease of pest and weed incidence resulting in higher and more stable yield (Tratwal and Gałęzewski, 2006). Experiments with cereal variety mixtures in Denmark and UK have shown that it is possible to obtain significantly higher yield in comparison to the average of components in pure stand under organic and also conventional farming (Østergård et al., 2005; Jones et al., 2006; Clarke et al., 2007). The results of our barley experiment do not strongly support the advantages of mixtures. No significant yield gain was obtained for mixtures in any growing system; only some insignificant advantages were observed under organic and conventional locations, and mostly for mixtures of breeding lines. According to the results of regression analysis, different tendencies were observed for mixtures; only mixture 1 had mean yield level over all locations significantly above average and the coefficient of regression 1.06 indicated fairly stable yield with a little trend to better adaptability to favourable growing conditions. Mixture 1 was composed of two distinct breeding lines from the cross combination 'Anni'/'Dziugiai', one of which was had a rapid early development, erect plant growth habit with a tendency to adaptation to unfavourable growing conditions $(b=0.66$; line 3$)$, and the other with prostrate plant growth habit, slower development and the most stable yield among the tested accessions $(b=1.01$; line 4$)$. This indicates that combination of such distinctive genotypes may result in a fairly stable mixture with average yield above the components.

It has been reported that mixtures can be an effective tool in reduction of disease incidence, as the necessity to use fungicides and the threat to lose the efficiency of disease resistance genes can be reduced (Martínez et al., 2007). In our study the only significant reduction of infection level in comparison to parents in pure stands was found for net blotch in mixture 2 in C1 location in 2010. However, significantly higher infection was observed for powdery mildew in two cases under conventional growing conditions. This contradiction may be explained by the fact that genotypes for the experiment were chosen without emphasis on resistance to diseases, and differences between the component varieties were often insignificant.

Growing of populations is considered as one of the ways to increase genetic diversity of self-pollinated cereal crops. As populations are heterogeneous they should be able to adjust to variable environments due to a compensation mechanism that is better than in pure lines and varieties (Wolfe, 2008; Wolfe et al., 2008; Finch et al., 2010). Extensive long-term experiments with composite cross populations for winter wheat are carried out in UK (Wolfe, 2006), where a tendency to yield higher in comparison to parental varieties under conventional and organic managements was reported. Populations developed with the aim to achieve high yield exceeded eight of nine parental varieties (Haigh et al., 2007). However, in testing in Germany the same popula- 
tions in general did not over yield the parents but provided more stable yield (Finckh et al., 2010). The ability of composite cross populations to better adapt to various growing conditions, when compared to parental varieties was shown by testing the previously mentioned wheat populations in Hungary (Wolfe and Döring. 2010). In our experiments the barley populations investigated originated from simple crosses between two parental varieties, and wheat populations from crosses between two or three parental varieties. Thus, the genetic diversity was not as high as in composite cross populations, as the expected advantage would likely not be very evident. Yield of barley populations was in between the level of parents in most cases and insignificant yield gain was obtained sometimes and mostly under organic growing conditions (Table 7). A tendency to form higher yield in conventional conditions was shown by three wheat populations (08-6 Astron/Bill and 08-7 Bilina/KOC/2520/97), but in organic conditions the yield of populations was between or less the parents. The results indicated that high yielding genotypes are not characterised by stability to unfavourable conditions. Regarding yield stability, barley populations were fairly stable with a tendency to suitability to unfavourable environments (regression model significant for population 2 only); wheat populations showed variable adaptability. Grain quality of wheat composite cross populations surpassed ten of twelve parents (Haigh et al., 2007), but in our barley experiments no significant gain for population grain quality traits was found. However, crude protein content and TGW surpassed parents insignificantly in some cases ands starch content and volume weight was below that of parents.

Quality traits of wheat populations grain in both growing conditions was also intermediate to that of the parents and did not exceeded the highest values of the best parents. Tendency to have highest TGW compared to that of parental varieties was found in both farming systems sites for populations. The grain quality values of all genotypes were lower in $\mathrm{O}$ conditions than in $\mathrm{C}$ conditions.

One of the most important basic breeding tasks for wheat is quality for milling and baking. Breeding for baking quality in wheat is determined largely by the common negative correlation between yield and grain protein. The main aim of breeding for organic farming is to select genotypes with acceptable yield and grain quality suitable for bread, by developing good lines combining high protein content with high gluten quality (Wolfe et al., 2008).

Winter hardiness is a very important trait for wheat in all environments in Latvian agroclimatical conditions. Studies have confirmed that resistance of populations to abiotic stress is closely connected with parent traits: the higher quality parents used in a cross, the better quality the resulting population, unless a negative genetic correlation proves otherwise (Murphy et al., 2007).

Döring et al. (2010) concluded that the advantage of highly diverse populations in ensuring higher yield level over that of monocultures is greater in more variable environments; the same relationship was found for variety mixtures, but it was weaker than in populations. Our results did not clearly support this idea, and there were some non-significant yield gains for barley under organic and also under conventional $\mathrm{C} 1$ locations, and for wheat under conventional conditions only. This might be explained by comparatively lower diversity of populations. Regarding the infection level with barley leaf diseases in organic and conventional growing systems, we can see opposite tendencies for net blotch and powdery mildew in respect to genetically diverse accessions and pure lines as well. Greater advantages over parents in respect to net blotch were found under conventional locations but in respect to powdery mildew — under organic locations.

\section{ACKNOWLEDGEMENTS}

This study is performed with financial support of European Social Fund co-financed project 2009/0218/1DP/ 1.1.1.2.0/09/APIA/VIAA/099.

\section{REFERENCES}

Chateil, C., Goldringer, I., Tarallo, L., Kerbiriou, C., Ponge, J-F, Salmon, S., Gachet, S., Porcher, E. (2010). Crop genetic diversity benefits farmland biodiversity in cultivated fields. In: Breeding for Resilience: A Strategy for Organic and Low-input Farming Systems? EUCARPIA 2nd Conference of the 'Organic and Low-Input Agriculture' Section 1-3, December 2010, Paris, France (pp. 39-42). Paris.

Clarke, S., Haigh, Z., Wolfe, M., Jones, H., Hinchsliffe, K. (2007). Varieties, mixtures and populations in organic oat. In: Proceedings of the COST SUSVAR Workshop on Varietal Characteristics of Cereal in Different Growing Systems with Special Emphasis on Below Ground Traits, Velence, Hungary, 29-31 May 2007 (pp. 67-70). Østergård, H., Backes, G., Kovács, G. (eds.). Denmark: Risø National Laboratory,.

Döring, T., Wolfe, M., Jones, H., Pearce, H., Zhan, J. (2010). Breeding for resilience in wheat - Nature's choice. In: Breeding for Resilience: A Strategy for Organic and Low-input Farming Systems? EUCARPIA 2nd Conference of the 'Organic and Low-Input Agriculture' Section 1-3, December 2010, Paris, France (pp. 45-48). Paris.

Eberhart, S. A., Russell, W. A. (1966). Stability parameters for comparing varieties. Crop Sci., 6 (1), pp. 36-40.

Finlay, K. W., Wilkinson, G. N. (1963). The analysis of adaptation in plant breeding program. Austral. J. Agr. Res., 14, 742-754.

Finckh, M. R., Gacek, E. S., Goyeau, H., Lannou, C., Mundt, C. C., Munk, L., Nadziak, J., Newtton, A. C., deVallavieille-Pope, C., Wolfe, M. S. (2000). Cereal variety and species mixtures in practice, with emphasis on disease resistance. Agronomie, 20, 813-837.

Finckh, M. R., Grosse, M., Weedon, O., Brumlop, S. (2010). Population developments from the F5 to the F9 of three wheat composite crosses under organic and conventional conditions. In: Breeding for Resilience: A Strategy for Organic and Low-input Farming Systems? EUCARPIA 2nd Conference of the 'Organic and Low-Input Agriculture' Section 1-3, December 2010, Paris, France (pp. 49-52). Paris.

Flath, K., Cooke, M., Waldow, F., Vogt-Kaute, W., Miedaner, T., Rodemann, B., Martinez, F., Newton, A., Jalli, M., Munk, L., Willas, J. (2006). Disease assessment. In: Handbook: Cereal Variety Testing for Organic Farming. Donner D., Osman A. (eds.). Driebergen: Louis Bolk Institute.

Haigh, Z., Bertholdsson, N., Clarke, S., Jones, H., Wolfe, M. S. (2007). Progress with variety mixtures and populations. In: Proceedings of the COST SUSVAR Workshop on Varietal Characteristics of Cereal in Different Growing Systems with Special Emphasis on Below Ground Traits, Velence, 
Hungary, 29-31 May 2007 (pp. 73-77). Østergård, H., Backes, G., Kovács, G. (eds.). Denmark: Risø National Laboratory,.

Jones, H., Clarke, S., Hinchsliffe, K., Wolfe, M. (2006). Husked and naked oat varieties and mixtures for organic farming systems. In: Proceedings of the COST SURVAR Workshop on Cereal Crop Diversity: Implications for Production and Products, La Besse, France 13-14 June 2006 (pp. 46-48). Østergard, H., Fortaine, L. (eds.). Paris: ITAB.

Konvalina, P. Moudrż, P. (2007). Choice of species and varieties of wheat for organic farming. In: Research for Rural Development. Agricultural Sciences (crop sciences, animal sciences). 16-18 May (pp. 22-29). Jelgava.

Lammerts van Bueren, E. T., Wilbois, K.-P., Østergård, H. (2007). European Perspectives of Organic Plant Breeding and Seed Production in Genomics Era. Supplement 89 (pp. 101-120). Witzenhausen: University of Kassel.

Lammerts van Bueren, E. T. (2010). Future breeding for organic and low-input agriculture: Integrating values and modern breeding tools for improving robustness. In: Breeding for Resilience: A Strategy for Organic and Low-input Farming Systems? EUCARPIA 2nd Conference of the 'Organic and Low-Input Agriculture' Section 1-3, December 2010, Paris, France (pp. 8-10). Paris.

Martínez, F., Cátedra, M., Rallo, P. (2007). Identification of several cultivars in Spanish wheat by means of SSR markers. In: Book of abstracts: EUCARPIA Symposium "Plant Breeding for Organic and Sustainable, Low-input Agriculture: Dealing with Genotype - Environment Interactions", 7-9 November 2007, Wageningen. (p. 60). The Netherlands: Wageningen University.

Murphy, K., Lammer, D., Lyon, S., Brady, C., Joness, S. S. (2005). Breeding for organic and low-input farming systems: An evolutionary-participatory breeding method for inbred cereal grains. Renew. Agr. Food Syst., 20, 48-55.

Murphy, K., Campbell, K. G., Lyon, S. R., Jones, S. S. (2007). Evidence of varietal adaptation to organic farming systems. Field Crops Res., 102, $172-177$.
Østergård, H., Kristensen, K., Jensen, J. W. (2005). Stability of variety mixtures of spring barley. In: Proceedings of the COST SUSVAR/ECO - PB Workshop on Organic Plant Breeding Strategies and the Use of Molekular Markers, Driebergen, The Netherlands, 17-18 January 2005. Lammerts van Bueren, E. T. (Ed.)

Swantson, J. S., Newton, A. C., Brosnan, J. M., Fotheringham, A., Glasgow, E. (2005). Determing the spirit of wheat varieties and mixtures. J. Cereal Sci., 42 (1), 127-134.

Tratwal, A., Gałęzewski, M. (2006). Variety and species mixtures - their influence on the main disease and pest occurrence. In: Proceedings of the COST SURVAR Workshop on Cereal Crop Diversity: Implications for Production and Products, La Besse, France 13-14 June 2006 (pp. 147-151). Østergard, H., Fortaine, L. (eds.). Paris: ITAB.

Wolfe, M. S. (2000). Crop strength through diversity. Nature, 406, 681-682.

Wolfe, M. (2008). Genetically diverse wheat populations: Their performance and use. In: Value for Cultivation and Use Testing of Organic Cereal Varieties: What are the key issues? (pp. 21-26). Rey, F., Fontaine, L., Osman, A., van Waes, J. (eds.). Proceedings of the COST ACTION $860-$ SUSVAR and ECO-PB Workshop, Brussels, Belgium.

Wolfe, M. (2006). Growing variety mixtures: Introduction. In: Proceedings of the COST SURVAR Workshop on Cereal Crop Diversity: Implications for Production and Products, La Besse, France 13-14 June 2006 (pp. 38-40). Østergard. H., Fortaine, L. (eds.). Paris: ITAB.

Wolfe, M. S., Baresel, J. P., Desclaux, D., Goldringer, I., Hoad, S., Kovacs, G., Löshenberger, F., Miedaner, T., Østergård, H., Lammberts van Bueren, E. T. (2008). Developments in breeding cereals for organic agriculture. Euphytica, 163 (3), 323-346.

Wolfe, M. S., Döring T. F. (2010). Steps toward an ecological future. In: Breeding for Resilience: A Strategy for Organic and Low-input Farming Systems? EUCARPIA 2nd Conference of the 'Organic and Low-Input Agriculture’ Section 1-3, December 2010, Paris, France (pp. 38-41). Paris.

Received 1 November 2012

\section{VAI ĢENĒTISKI DAUDZVEIDĪGAM MATERIĀLAM IR PRIEKŠROCĪBAS GRAUDAUGU SELEKCIJĀ BIOLOĢISKAI LAUKSAIMNIECĪBAI?}

Bioloǵiskajā lauksaimniecībā nepieciešamas šķirnes, kurām raksturīga augsta pielāgošanās spēja nelabvēlīgiem vides apstākliem. Lai paaugstinātu pašapputes augu konkurētspēju, saglabātu pietiekamu ražību un graudu kvalitāti, tiek izmantoti škirņu maisījumi un populācijas. Divu gadu izmēǵinājumos tika izvērtētas vasaras miežu šḳinnu maisījumu un hibrīdo populāciju, kā arī ziemas kviešu populāciju priekšrocības salīdzinājumā ar tīrajām līnijām un vecākaugiem. Miežu genotipu maisījumiem un populācijām netika konstatētas pārliecinošas priekšrocības ne bioloǵiskos, ne konvencionālos audzēšanas apstākḷos. Labāki rezultāti attiecībā uz ražu un tūkstoš graudu masu nelabvēlīgos audzēšanas apstākḷlos novēroti biolog̣iskās lauksaimniecības vajadzībām izlasītām selekcijas līnijām. Attiecībā uz genotipu maisījumiem secināts, ka atšķirīgu genotipu kombinēšana var dot salīdzinoši stabilu maisījumu ar ražas līmeni virs vidējā. Graudu ražas un kvalitātes rādītāji bioloğiskajos apstākḷos visiem izvērtētajiem genotipiem bija zemāki nekā konvencionālajā laukā. Abos izmēǵinājumu gados un visas audzēšanas vietās ziemāju kviešu ražas limitējošs faktors bija škiiṇu ziemcietība. Populāciju ziemcietība bija atkarīga no krustošanā izmantoto škirņu izturības pret abiotiskajiem faktoriem. Kviešu populāciju ražība un graudu kvalitāte bioloğiskajā laukā nebija augstāka, salīdzinot ar vecākaugiem. Nonākot sliktākos audzēšanas apstākḷos, augstražīgo populāciju ražas līmenis krasi pazeminājās. Tas liecina par genotipu sliktu adaptācijas spēju. 